\title{
Length-weight relationships of eleven mesopelagic fishes from oceanic islands of the Southwestern Tropical Atlantic
}

\author{
Eduardo Leandro N. 1, ${ }^{\star}$, Mincarone Michael M. ${ }^{2}$, Villarins Bárbara T. ${ }^{2}$, Frédou Thierry ${ }^{1}$, \\ Lira Alex Souza ${ }^{1}$, Bertrand Arnaud 1,3, 4, Lucena-Frédou Flavia ${ }^{1}$
}
${ }^{1}$ Departamento de Pesca e Aquicultura; Universidade Federal Rural de Pernambuco; Recife, Brazil
${ }^{2}$ Núcleo em Ecologia e Desenvolvimento Socioambiental de Macaé; Universidade Federal do Rio de Janeiro; Macaé ,Brazil
${ }^{3}$ Departamento de Oceanografia; Universidade Federal de Pernambuco; Recife, Brazil
${ }^{4}$ Institut de Recherche pour le Développemen, Sète ,France

* Corresponding author : Leandro N. Eduardo, email address : leandronole@hotmail.com

\begin{abstract}
:
This study provides the length-weight relationship for eleven mesopelagic fishes from oceanic islands of the Southwestern Tropical Atlantic: Bonapartia pedaliota, Sigmops elongatus (Gonostomatidae), Argyropelecus aculeatus, Argyropelecus affinis, Argyropelecus sladeni, Sternoptyx diaphana, Sternoptyx pseudobscura (Sternoptychidae), Malacosteus niger, Thysanactis dentex (Stomiidae), Melanonus zugmayeri (Melanonidae), and Ectreposebastes imus (Setarchidae). Data were collected during a scientific survey (2017) around Rocas Atoll, Fernando de Noronha Archipelago and adjacent seamounts, using a micronekton trawl (side sispilength of body mesh: $40 \mathrm{~mm}$, side 35 stations from 0 to $1,113 \mathrm{~m}$ depth. A new maximum standard length for Bonapartia pedaliota and Ectreposebastes imus are also provided.
\end{abstract}




\section{INTRODUCTION}

In the western Tropical Atlantic, the Fernando de Noronha Archipelago, Rocas Atoll and adjacent seamounts host a remarkable biodiversity (Fiedler et al., 2016; Hazin et al, 1998). For this reason, the marine ichthyofauna of this large biogeographic unit categorized as Ecologically or Biologically Significant Marine Areas - EBSA (CBD, 2014) has been studied by many authors (Dominguez et al., 2016; Kikuchi \& Schobbenhaus, 2002; Oliveira et al., 2011). However, most efforts focused on fishes living near to the surface $(0-200 \mathrm{~m})$ and few studies described the mesopelagic zone (200-1000 m depth) of this region, which is considered as one of the most understudied of the world ocean (St. John et al., 2016).

The mesopelagic community is a key resource for higher trophic levels, maintaining part of the marine biodiversity and playing an important role in carbon sequestration and thus on the biological carbon pump (Proud et al, 2017; St. John et al., 2016). To better account for the role of this community in the ecosystem structure and function, a prerequisite is to have the necessary biological information. One of such key basic knowledge concerns the length-weight relationships (LWR) that are one of the requisites for fisheries management and conservation (Froese, 2006; Froese et al., 2011). Indeed, LWRs are used to estimate body weight by length measurements, assess the condition factor or well-being of species of interest, as well as for the calculation of production and biomass of a fish stock (Froese, 2006). Despite this, information on LWRs are still lacking for many deep-sea fishes. Here, we provide new LWRs for eleven mesopelagic fish species collected along the northeast Brazilian oceanic islands, in order to increase the biological data and general knowledge of these species.

\section{MATERIAL AND METHODS}

The study area comprises the northeast Brazilian oceanic islands, including Rocas Atoll ( $\left.3^{\circ} 52^{\prime} \mathrm{S}, 33^{\circ} 49^{\prime} \mathrm{W}\right)$, Fernando de Noronha Archipelago (3⒌ $\left.50^{\prime} \mathrm{S}, 32^{\circ} 25^{\prime} \mathrm{W}\right)$ and adjacent seamounts. Data were collected during the scientific survey ABRACOS (Acoustics along the BRAzilian COaSt) conducted on board the RV Antea, from 9th April to 6th May 2017. Mesopelagic sampling was conducted using a micronekton trawl

61 (side length of body mesh: $40 \mathrm{~mm}$, side length of cod-end mesh: $10 \mathrm{~mm}$ ) at 35 stations from 0 to $1113 \mathrm{~m}$ depth. After capture, the material was fixed in a $4 \%$ formalin solution for one month and then preserved in a $70 \%$ alcohol solution for proximally six months before processing for length and weight. At the laboratory, species were identified, 
measured (nearest $0.1 \mathrm{~cm}$ of standard length, SL) and weighed (nearest $0.01 \mathrm{~g}$ of total weight, TW). All specimens were deposited in the Fish Collection of the Núcleo em Ecologia e Desenvolvimento Socioambiental de Macaé (NPM), Universidade Federal do Rio de Janeiro (NUPEM/UFRJ).

The parameters of the LWR were estimated through the equation: $T W=a \times S L^{b}$, where $T W$ is the total weight $(\mathrm{g}), S L$ is the standard length $(\mathrm{cm}), a$ is a constant being the initial growth index and $b$ is the slope of the regression. Prior to the calculation of LWRs, the relationship plots were executed for visual inspection and removal of outliers (Froese \& Binohlan, 2000). The significance of the regression was tested by ANOVA and the degree of association between $T W$ and $S L$ was calculated by the determination coefficient $\left(r^{2}\right)$. We only included LWRs for species with $n>30$, except for three species for which a wide fish-length range was available.

\section{RESULTS}

A total of 11 species belonging to five families and three orders were analysed (Table 1). All regressions were highly significant $(\mathrm{P}<0.01)$, with the coefficient of determination $\left(\mathrm{r}^{2}\right)$ ranging from 0.9511 to 0.9862 . The value of $b$ varied between 2.66 for Sternoptyx pseudobscura and 3.22 for Sigmops elongatus, while the parameter $a$ ranged between 0.0012 for Thysanactis dentex and 0.0250 for Ectreposebastes imus.

\section{DISCUSSION}

This work provides the first LWR for six species: $S$. pseudobscura, $B$. pedaliota, S. elongatus, T. dentex, M. zugmayeri, and E. imus. LWR information has been previously available for A. aculeatus, A. affinis, A. sladeni, S. diaphana, and $M$. niger, but it was based on a small length range, small sample size $(<5)$ and/or without the descriptive statistics of the relationships (Alpoim et al., 2002; Davison et al., 2015). All species presented here but A. aculeatus and M. niger, have no LWRs available in FishBase. In addition, the highest standard-length values for Bonapartia pedaliota and Ectreposebastes imus are reported herein.

As established by Froese (2006), the allometric coefficients for all LWRs were within the expected range of 2.5-3.5. These values are reflection of intrinsic characteristics and process of adaptations of each species, as ontogenetic reproductive or environmental variations, mainly between sexes (Froese, 2006). In addition, fixation 
in alcohol and formaldehyde can affect length and weight measurements through the shrinking and dehydration of specimens. For that reason, we recommend consider the LWRs presented here as being tentative.

Overall, this study increases the knowledge on mesopelagic fishes, providing basic biological information useful for further studies in ecology, conservation, and fisheries assessment.

\section{ACKNOWLEDGEMENTS}

We acknowledge the French oceanographic fleet for funding the at-sea survey ABRACOS (http://dx.doi.org/10.17600/17004100) and the officers and crew of the RV Antea for their contribution to the success of the operations. The present study could not have been done without the work of all participants from the BIOIMPACT (UFRPE) and LIZ (UFRJ) laboratories. We thank the CNPq (Brazilian National Council for Scientific and Technological Development) for providing student scholarship to LNE and ASL, and research grant for TF and FLF. This work is a contribution to the LMI TAPIOCA, CAPES/COFECUB program (88881.142689/2017-01), and PADDLE project (funding by the European Union's Horizon 2020 research and innovation programme - grant agreement No. 73427).

\section{REFERENCES}

Alpoim, R., Ávila de Melo, A., Banon, R., Casas, M., Cervino, S., Junquera, S., Martín, I., Murua, H., Paz, X., Pérez-Gándaras, G., del Río, J. L., Rodríguez-Marín, E., Saborido-Rey, F., dos Santos, E. J., \& Vásquez, A. (2002). Distribution and main characteristic of fish species on Flemish Cap based on the 1988-2002 EU-surveys in July. NAFO SCR 02/72(N4685), 1-73.

CBD. (2014). Ecologically or Biologically Significant Marine Areas (EBSAs). Special places in the world's oceans. (2nd ed.). Recife: Secretariat of the Convention on Biological Diversity.

Davison, P., Lara-Lopez, A., \& Anthony Koslow, J. (2015). Mesopelagic fish biomass in the southern California current ecosystem. Deep-Sea Research Part II: Topical Studies in Oceanography, 112, 129-142. https://doi.org/10.1016/j.dsr2.2014.10.007

Dominguez, P. S., Zeineddine, G. C., Rotundo, M. M., Barrella, W., \& Ramires, M. (2016). A pesca artesanal no arquipélago de fernando de noronha (PE). Boletim do Instituto de Pesca, 42(1), 241-251. https://doi.org/10.5007/16782305.2016v42n1p241

Fiedler, F. N., Sales, G., Giffoni, B. B., Port, D., Ana, R. S., Barreto, A. S., \& Schwingel, P. R. (2016). Hyperiid amphipods around the seamounts and islands off 
northeastern Brazil. Brazilian Journal of Oceanography, 64(4), 339-351.

Froese, R. (2006). Cube law, condition factor and weight-length relationships: history, meta-analysis and recommendations. Journal of Applied Ichthyology, 22(4), 241253. https://doi.org/10.1111/j.1439-0426.2006.00805.x

Froese, R., \& Binohlan, C. (2000). Empirical relationships to estimate asymptotic length, length at first maturity and length at maximum yield per recruit in fishes, with a simple method to evaluate length frequency data. Journal of Fish Biology, 56(4), 758-773. https://doi.org/10.1006/jfbi.1999.1194

Froese, R., Tsikliras, A. C., \& Stergiou, K. I. (2011). Editorial note on weight-length relations of fishes. Acta Ichthyologica et Piscatoria, 41(4), 261-263. https://doi.org/10.3750/AIP2011.41.4.01

Hazin, F. H. V, Zagaglia, J. R., Broadhurst, M. K., Travassos, P. E. P., \& Bezerra, T. R. Q. (1998). Review of a small-scale pelagic longline fishery off northeastern Brazil. Marine Fisheries Review, 60, 1-8.

Kikuchi, R. K. P., \& Schobbenhaus, C. (2002). Atol das Rocas, litoral do Nordeste do Brasil - Único atol do Atlântico Sul Equatorial Ocidental. In C. Schobbenhaus, D. A. Campos, E. T. Queiroz, M. Winge \& M. L. C. Berbert-Born (eds.). Sítios Geológicos e Paleontológicos do Brasil. Brasilia: DNPM/CPRM (SIGEP), pp. 379-393. https://doi.org/10.1590/S1676-06032008000300013

Oliveira, P. G. V., Oliveira, D. S., Pinheiro, P. B., Hazin, F. H. V., Carvalho, F. C., Veras, D. P., \& Silva, M. B. (2011). Population structure and growth of young lemon shark, Negaprion brevirostris (Poey, 1868), at the Atol das Rocas Biological Reserve, Brazil. Revista de Gestão Costeira Integrada, 11(4), 389-395. https://doi.org/10.5894/rgci236

Proud, R., Cox, M. J., \& Brierley, A. S. (2017). Biogeography of the global ocean's mesopelagic zone. Current Biology, 27(1), 113-119. https://doi.org/10.1016/j.cub.2016.11.003

St. John, M. A., Borja, A., Chust, G., Heath, M., Grigorov, I., Mariani, P., Martin, A. P., \& Santos, R. S. (2016). A dark hole in our understanding of marine ecosystems and their services: Perspectives from the mesopelagic community. Frontiers in Marine Science, 3, 1-6. https://doi.org/10.3389/fmars.2016.00031

Tchamabi, C. C., Araujo, M., Silva, M., \& Bourlès, B. (2017). A study of the Brazilian Fernando de Noronha Island and Rocas Atoll wakes in the tropical Atlantic. Ocean Modelling, $\quad 111, \quad 9-18 . \quad$ https://doi.org/10.1016/j.ocemod.2016.12. 
167 Table 1. Descriptive statistics and parameters of LWRs for 12 deep-sea fishes caught using a micronekton trawl at the northeast Brazilian oceanic 168 islands and seamounts, from 9th April to 6th May 2017. SL $=$ Standard Length, TW = Total Weight, $\boldsymbol{a}=$ initial growth index, $\boldsymbol{b}=$ slope of the 169 regression and $\mathbf{r} \mathbf{2}=$ determination coefficient.

\begin{tabular}{|c|c|c|c|c|c|c|c|c|}
\hline \multirow[t]{2}{*}{ Taxa } & \multirow[t]{2}{*}{$\mathbf{n}$} & \multicolumn{2}{|c|}{ SL (cm) } & \multicolumn{2}{|c|}{ TW (g) } & \multicolumn{2}{|c|}{ Regression parameters } & \multirow[t]{2}{*}{$\mathbf{r 2}$} \\
\hline & & Min & Max & Min & Max & $\mathbf{a}$ & b $(95 \%$ CL $)$ & \\
\hline \multicolumn{9}{|l|}{ Stomiiformes } \\
\hline \multicolumn{9}{|l|}{ Gonostomatidae } \\
\hline Bonapartia pedaliota Goode \& Bean, 1896 & 85 & 3.7 & 7.5 & 0.4 & 2.7 & $0.0074(0.0058-0.0094)$ & $2.94(2.80-3.08)$ & 0.9571 \\
\hline Sigmops elongatus (Günther, 1878) & 35 & 4.9 & 25 & 0.2 & 28 & $0.0015(0.0009-0.0023)$ & $3.229(3.07-3.39)$ & 0.9814 \\
\hline \multicolumn{9}{|l|}{ Sternoptychidae } \\
\hline Argyropelecus aculeatus Valenciennes, 1850 & 49 & 3 & 8.2 & 0.8 & 20.9 & $0.0350(0.0245-0.0496)$ & $2.996(2.77-3.21)$ & 0.9529 \\
\hline Argyropelecus affinis Garman, 1899 & 260 & 2.8 & 7.8 & 0.31 & 6.09 & $0.0218(0.0183-0.0258)$ & $2.807(2.70-3.91)$ & 0.9511 \\
\hline Argyropelecus sladeni Regan, 1908 & 26 & 2 & 6.6 & 1.15 & 7.2 & $0.0425(0.0257-0.0705)$ & $2.703(2.39-3.01)$ & 0.9618 \\
\hline Sternoptyx diaphana Hermann, 1781 & 600 & 1.2 & 4.3 & 0.1 & 4.3 & $0.0570(0.0370-0.0770)$ & $2.89(2.79-2.99)$ & 0.9275 \\
\hline Sternoptyx pseudobscura Baird, 1971 & 51 & 1.3 & 5.6 & 0.24 & 6.6 & $0.0754(0.0582-0.0970)$ & $2.663(2.45-2.88)$ & 0.9655 \\
\hline \multicolumn{9}{|l|}{ Stomiidae } \\
\hline Malacosteus niger Ayres, 1848 & 33 & 6.3 & 18.1 & 1.5 & 34.4 & $0.0057(0.0009-0.0030)$ & $2.956(2.74-3.17)$ & 0.9635 \\
\hline Thysanactis dentex Regan \& Trewavas, 1930 & 35 & 4.3 & 14.5 & 0.1 & 10.6 & $0.0012(0.0009-0.0012)$ & $3.197(3.07-3.33)$ & 0.9868 \\
\hline \multicolumn{9}{|l|}{ Gadiformes } \\
\hline \multicolumn{9}{|l|}{ Melanonidae } \\
\hline Melanonus zugmayeri Norman, 1930 & 20 & 6.4 & 19.1 & 1.06 & 32.31 & $0.0036(0.0018-0.0071)$ & $2.973(2.68-3.26)$ & 0.9623 \\
\hline \multicolumn{9}{|l|}{ Scorpaeniformes } \\
\hline \multicolumn{9}{|l|}{ Setarchidae } \\
\hline Ectreposebastes imus Garman, 1899 & 25 & 5.2 & 23.4 & 3.43 & 290.3 & $0.0250(0.0138-0.0482)$ & $3.025(2.81-3.24)$ & 0.9728 \\
\hline
\end{tabular}

